\title{
Humoral Immunodeficiency to Bacterial Antigens in Patients with Juvenile Onset Diabetes Mellitus
}

\author{
H. Ludwig, M. Eibl, G. Schernthaner, W. Erd and W. R. Mayr \\ II. Medical Clinic, Institute of Immunology and Institute of Blood Group Serology*, University of Vienna, Vienna, Austria
}

\begin{abstract}
Summary. Humoral immunity to bacterial antigens was tested in 49 tissue typed patients with juvenile onset diabetes mellitus (JOD) and in 50 healthy controls. The number of patients with agglutinins to $\mathrm{E}$. coli and staphyloccoci was significantly lower compared to controls $(p<0.001, p<0.01$ respectively). Missing antibody formation to pertussis and diphtheria toxoid could also be detected in a higher percentage of JOD patients than of controls $(p<$ $0.05 ; \mathrm{p} \simeq 0.05$, respectively). By contrast heteroagglutinins to sheep and rabbit erythrocytes were found in similiar proportion in both groups and the values of immunoglobulin serum concentrations showed no difference between patients and controls. In addition no correlation between antibody formation and genes of the HLA complex was found. It is suggested that the severely reduced agglutinin formation to bacterial antigens might be partly responsible for susceptibility to bacterial infections in juvenile diabetics.
\end{abstract}

Key words: Humoral immunodeficiency, agglutinins to bacterial antigens, heteroagglutinins, serum immunoglobulin concentration, suspectibility to infections, HLA gene complex.

It is commonly stated that patients with diabetes mellitus (DM) are more susceptible to infections than healthy subjects, although epidemiologic studies of various types of infections in patients with DM have shown conflicting results; however, when infections do occur in diabetic patients, they tend to be protracted and severe [8].

\footnotetext{
* National Blood Group Reference Laboratory (WHO), National Tissue Typing Reference Laboratory (Council of Europe).
}

Recent investigations about cell-mediated immune reactivity showed normal lymphocyte transformation to PHA in metabolically well controlled patients [18], whereas lymphocyte transformation was impaired in poorly controlled diabetics [13]. A reduction of polymorphonuclear function, namely of chemotaxis $[9,15,17]$ and phagocytosis [2], was found especially in diabetics with ketoacidosis or hyperglycemia without ketoacidosis $[2,16]$.

Only a few, rather controversial, data about the humoral antibacterial immunity have been reported $[14,19,24]$. Since an impairment of phagocytosis could be shown [17] in juvenile onset diabetes mellitus (JOD), it seemed interesting to investigate humoral antibacterial immunity to ubiquitous bacterial antigens in juvenile diabetics. In addition we looked for a possible correlation between antibody formation and genes of the HLA complex.

\section{Material and Methods}

\section{Subjects Investigated}

49 patients (mean age: 34.5 years) with insulin dependent diabetes were studied. All patients included in this investigation were in good metabolic control; the mean age at onset of the disease was 23.4 years, the mean duration of the disease was 13.1 years. 50 healthy, age and sex matched blood donors (mean age: 33.1 years) were studied as controls.

\section{Methods}

Agglutinins to E. coli and staphylococci [4], pertussis [1] and heteroagglutinins were determined by standard techniques. A titre higher than $1: 8$ (for pertussis agglutinins $1: 4$ ) was considered positive. Subjects with antibody titres equal to or higher than $1: 64$ were 
Table 1. Heteroagglutinins and antibodies to bacterial antigens in juvenile diabetics and controls

\begin{tabular}{lrll}
\hline Determination of & $\begin{array}{l}\text { JOD } \\
\mathrm{n}=49\end{array}$ & $\begin{array}{l}\text { Controls } \\
\mathrm{n}=50\end{array}$ & $\mathrm{p}$ \\
\hline E. coli-aggl. & $19(38,7 \%)$ & $44(88,0 \%)$ & $<0,001$ \\
staphyloc.-aggl. & $31(63,2 \%)$ & $43(86,0 \%)$ & $<0,01$ \\
pertussis-aggl. & $6(12,2 \%)$ & $15(30,0 \%)$ & $<0,05$ \\
diphtheria-antitox. & $23(46,9 \%)$ & $33(66,0 \%)$ & $\simeq 0,05$ \\
heteroaggl. (sheep) & $33(67,3 \%)$ & $34(68,0 \%)$ & n.s. \\
heteroaggl. (rabbit) & $49(100 \%)$ & $49(98,0 \%)$ & n.s. \\
\hline
\end{tabular}

Table 2. Missing evidence for correlation between antibody prevalence and those HLA antigens associated with JOD

\begin{tabular}{lccc}
\hline $\begin{array}{l}\text { Subjects studied } \\
\text { Controls n }=50\end{array}$ & $\begin{array}{c}\text { HLA-B8 } \\
9(18 \%)\end{array}$ & $\begin{array}{c}\text { HLA-BW15 } \\
5(10 \%)\end{array}$ & $\begin{array}{l}\text { HLA-CW3 } \\
10(20 \%)\end{array}$ \\
\hline $\begin{array}{l}\text { JOD-patients } \\
\mathbf{n}=49\end{array}$ & $22(44,8 \%)$ & $14(28,5 \%)$ & $19(38,7 \%)$ \\
\hline $\begin{array}{l}\text { E. coli-aggl. pos. JOD } \\
\mathbf{n}=19\end{array}$ & $8(42,1 \%)$ & $4(21,0 \%)$ & $7(36,8 \%)$ \\
\hline $\begin{array}{l}\text { E. coli-aggl. neg. JOD } \\
\mathbf{n}=30\end{array}$ & $14(46,6 \%)$ & $10(33,3 \%)$ & $12(40,0 \%)$ \\
\hline $\begin{array}{l}\text { Staph. aggl. pos. JOD } \\
\mathbf{n}=31\end{array}$ & $15(48,3 \%)$ & $8(25,8 \%)$ & $11(35,4 \%)$ \\
\hline $\begin{array}{l}\text { Staph. aggl. neg. JOD } \\
\mathbf{n}=18\end{array}$ & $7(38,8 \%)$ & $6(33,3 \%)$ & $8(44,4 \%)$ \\
\hline $\begin{array}{l}\text { Dipht.-antitox. pos. JOD } \\
\mathbf{n}=23\end{array}$ & $12(52,1 \%)$ & $6(26,0 \%)$ & $8(34,8 \%)$ \\
\hline $\begin{array}{l}\text { Dipht.-antitox. neg. JOD } \\
\mathrm{n}=26\end{array}$ & $10(38,4 \%)$ & $8(30,8 \%)$ & $11(42,3 \%)$ \\
\hline
\end{tabular}

(Since pertussis agglutinins were found only in five patients, data are not included in this table).

considered to be high responders. The toxin neutralisation test in guinea pigs [22] was used to determine diphtheria antitoxins. Serum levels of immunoglobulins were measured by radial immunodiffusion and compared with the range of normal values as given by Stiehm and Fudenberg [23].

Tissue typing was performed by the NIH microlymphocytotoxicity test.

Statistical significance was evaluated with the $\chi^{2}$ test.

\section{Results}

\section{Agglutinins to Bacterial Antigens and Heteroaggluti- nins}

The number of subjects with antibodies to bacterial antigens was significantly lower in the JOD patients compared to healthy controls (Table 1 ). The most significant difference $(p<0.001)$ was observed in the numbers of patients and controls with E. coli-agglutinins. These antibodies, which were found in $88 \%$ of the controls, could be detected in only $38.7 \%$ of the JOD patients.

The frequency of staphylococcal agglutinins was also reduced in diabetics: Staphylococci antibodies were found in $63 \%$ of the patients and in $86 \%$ of the controls $(p<0.01)$. In addition a lack of antibodies to pertussis and diphtheria toxoid could be detected in a higher percentage of JOD patients than in the controls ( $p<0.05, p \simeq 0.05$ respectively).

By contrast heteroagglutinins to sheep and rabbit erythrocytes were found in similar proportion in both groups (Table 1).

\section{Antibody Production and the HLA Gene Complex}

In the patients as well as in the controls no significant correlation between the prevalence of bacterial antibodies and HLA antigens, especially these HLA antigens (HLA-B8, HLA-BW15 and HLA-CW3) reported to be associated with JOD [20] could be found (Table 2). Likewise a lack of correlation was observed when only high (with titers equal or higher than $1: 64$ ) or non responders (with titers lower than $1: 8$ ) groups were analysed.

\section{Serum Immunoglobulin Concentrations}

The mean values of serum immunoglobulin concentrations (IgG, IgA, IgM) did not show any difference between patients and control groups. The number of subjects with increased or decreased serum immunoglobulin levels were almost identical in the groups under investigation.

\section{Discussion}

The present study indicates impaired antibody formation to bacterial antigens in patients with JOD. At the time of investigation all patients were in complete metabolic control. Thus, antibacterial immune deficiency seems to be associated with the disease itself, although further aggravation of the defect might occur with progressing metabolic decompensation. Da Costa [7] was able to report as early as 1907 an impaired opsonic index in DM. At that time no further technical facilities were available which would have allowed a more precise specification of the defect. In subsequent studies, favouring as well as contradicting data regarding a defect of antibody synthesis were published $[14,19,24]$.

In diabetics E. coli are often the cause of urinary 
tract infections and staphylococci frequently cause skin infections [6]. When infections occurred in our patients, it was often these specific microorganisms that could be isolated. The reported reduced agglutinin formation to E. coli and staphylococci might be partly responsible for increased susceptibility to these pathogens.

It was noted that antibodies to pertussis and diphteria toxoid were found less frequently in diabetics, although the number of subjects vaccinated with these antigens was approximately the same (35 patients were vaccinated with pertussis and 39 with diphtheria antigens, and 37 and 40 of the controls) in both groups. Interestingly, 5 of the patients who were previously vaccinated with pertussis contracted the disease later. This is a fairly high number for a relatively small group. The normal incidence of the heteroagglutinins permits the assumption that the observed antibody deficiency might be restricted to certain bacterial antigens only; the normal serum immunoglobulin concentration in our JOD patients and in diabetics studied by investigators elsewhere [3] are in accordance with these findings.

In animal models an association between antibody formation and genes of the major histocompatibility locus exists $[5,11]$. In insulin treated diabetics first results show a possible correlation between insulin antibody production and HLA-BW15, which is one of the HLA antigens associated with JOD [10]. It could also be shown that the frequencies of HLA-B8, HLA-BW15 and HLA-CW3 antigens are dependent on the patients' age at onset of the disease [21] and that glucose intolerance is mainly found in the blood relations (under age 35) of JOD patients who are positive for these antigens [12]. In the present investigation neither in the moderate nor in the high bacterial antibody responders nor in the non-responders could such an association be detected. Due to the relatively small number of patients studied, definite conclusions on the lack of a correlation between HLA antigens and bacterial antibodies cannot be drawn at present.

Other variables in the immune system, e.g. complement levels [3], the ratio of $\mathrm{B}$ and $\mathrm{T}$ lymphocytes [13] and the lymphocyte transformation rate to PHA, were found to be normal in well controlled diabetics $[13,18]$. Those functions primarily responsible for antibacterial immunity, namely phagocytosis and chemotaxis, are particularly reduced in diabetics under partial as well as complete metabolic control. These impairments of polymorphonuclear (PMN) function together with the specific antibody deficiency might contribute to the increased susceptibility to certain infections.

The mechanisms leading to the impairment of
PMN function and the specific antibody deficiency are unknown. Very recently Molenaar et al. [15] reported impaired leucocyte chemotaxis also in healthy nondiabetic parents and siblings of JOD patients. On the basis of these findings it was suggested that genetic factors might possibly be responsible for the chemotactic defect. It is conceivable that similar mechanisms may play a part in the observed humoral immunodeficiency. The importance of a possible genetic regulation of these antibacterial defects is under further investigation in family studies of JOD patients.

Acknowledgements. We like to acknowledge the excellent technical assistance of Mrs. Milada Miricka and Mrs. Christine Sitko.

\section{References}

1. Alexander H. E., MacPherson, C., Redman, W.: Quantitative method for measuring $\mathrm{H}$ Pertussis antibody. Pediatrics 5, 443-447 (1950)

2. Bagdade, J. D., Root, R. K., Bulger, R. J.: Impaired leucocyte function in patients with poorly controlled diabetes. Diabetes 23, 9-15 (1974)

3. Balch, H. H., Watters, M.: Blood bactericidal studies and serum complement in diabetic patients. J. surg. Res. 3, 199-212 (1963)

4. Benacerraf, B., Sebestyen, M. M., Schlossmann, St.: A quantitative study of the kinetics of blood clearance of $\mathrm{P}^{32}$-labelled Escherichia coli and staphylococci by the reticuloendothelial system. J. exp. Med. 109, 27-48 (1959)

5. Benacerraf, B., McDevitt, H. O.: Histocompatibility-linked immune response genes. Science 175, 273-279 (1972)

6. Campbell, I. W., Munro, J. F., McCuish, A. C., Duncan, L. J. P. Infection and severe diabetic metabolic decompensation. Practitioner 213, 813-818 (1974)

7. Da Costa, J. C.: The opsonic index in diabetes mellitus. Ann. J. Med. Sci. 134, 57-70 (1907)

8. Editorial: Diabetes mellitus and pyelonephritis. New Engl. J. Med. 261, 1247-1248 (1959)

9. Hill, H. R., Sauls, H. S., Dettloff, J. L., Quie, P. G.: Impaired leukotactic responsiveness in patients with juvenile diabetes mellitus. Clin. Immunol. Immunopathol. 2, 295-403 (1974)

10. Jansen, F. K., Bertrams, J., Grüneklee, D., Drost, H., Reis, H. E., Bever, J., Kuwert, E., Gries, F. A., Altrock, E.: Genetic association of the insulin-antibody production with histocompatibility (HLA)-antigens in diabetics. Diabetologia 11, $352-352$ (1975)

11. Keck, K.: Ir-gene control of immunogenicity of insulin and A-chain loop as a carrier determinant. Nature (Lond.) 254, 78-79 (1975)

12. Ludwig, H., Mayr, W. R., Schernthaner, G.: Glucose tolerance tests in HLA-typed relatives of patients with juvenile onset diabetes mellitus. Lancet 1975 II, 1152-1153

13. McCuish, A. C., Urbaniak, S. J., Campbell, C. J., Duncan, L. J. P., Irvine, W. J.: Phytohaemagglutinin transformation and circulating lymphocyte subpopulations in insulin-dependent diabetic patients. Diabetes 23, 708-712 (1974)

14. Marble, A., White, H. J., Fernald, A. T.: The nature of the lowered resistance to infection in diabetes mellitus. J. clin. Invest. 17, 423-430 (1938) 
15. Molenaar, D. M., Palumbo, P. J., Wilson, W. R., Ritts, R. E.: Impaired leucocyte chemotaxis in nondiabetic relatives of patients with juvenile onset diabetes. Diabetes 24, 401 (1975)

16. Mowat, A. G., Baum, J.: Chemotaxis of polymorphonuclear leukocytes from patients with diabetes mellitus. New Engl. J. Med. 284, 621-627 (1971)

17. Niethammer, D., Heinze, E., Teller, W., Kleihauer, E., Wildfeuer, A., Haferkamp, O.: Impairment of granulocyte function in juvenile diabetes. Klin. Wschr. 53, 1057-1060 (1975)

18. Ragab, A. H., Hazlett, B., Cowan, D. H.: Response of peripheral blood lymphocytes from patients with diabetes mellitus to phytohaemagglutinin and Candida Albicans antigen. Diabetes 21, 906-907 (1972)

19. Richardson, R.: Immunity in diabetes. Influence of diabetes on the development of antibacterial properties in the blood. J. clin. Invest. 12, 1143-1149 (1933)

20. Schernthaner, G., Mayr, W. R., Pacher, M., Ludwig, H., Erd, W., Eibl, M.: HL-A8, W15 and T3 in juvenile onset diabetes mellitus. Horm. Metab. Res, 7, 521-522 (1975)
21. Schernthaner, G., Ludwig, H., Mayr, W. R.: Juvenile diabetes mellitus. HLA-antigen frequencies dependent on the age of onset of the disease. J. Immunogenetics 3, 117-121 (1976)

22. Schmidt, H.: Die Praxis der Auswertung von Toxinen und Antitoxinen. Jena: G. Fischer Verlag 1931

23. Stiehm, E. R., Fudenberg, H. H.: Serum levels of Immunoglobulins in health and disease. A survey. Pediatrics 37, 715-727 (1966)

24. Wale, R. S., Madders, K.: Staphylococcal toxoid in the treatment of diabetes. Brit. J. exp. Path. 17, 279-281 (1936)

Received: December 16, 1975, and in revised form: April 5, 1976

Dr. H. Ludwig

II. Med. Universitätsklinik

Garnisonsgasse 13

A-1097 Wien 9

Austria 